\title{
Daya Terima Permen Jelly Buah Pedada (Sonneratia Caseolaris) dengan Penambahan Karagenan
}

\author{
Dwi Tria Ramadani ${ }^{1}$, Dini Wulan Dari ${ }^{2}$, Aisah $^{3}$ \\ ${ }^{1-3}$ Program Studi S1 Ilmu Gizi, Sekolah Tinggi Ilmu Kesehatan Baiturrahim Jambi \\ Email : sungtriahee@gmail.com
}

Submitted :025/10/2019

Accepted: 06/02/2020

Published: 14/03/2020

\begin{abstract}
Pedada fruit (Sonneratia caseolaris) is one of the mangrove varieties that has a high nutritional content and has the potential as an antioxidant. In general, pedada is still underutilized by the community because it tastes sour and feels tight when consumed directly. One of the efforts in utilizing the pedada fruit is processing it into jelly candy. The purpose of this study was to determine the acceptability (color, flavour, texture and taste) of pedada jelly candy with the addition of carrageenan. This research is an experimental design. This study was used a completely randomized design (CRD) of 2 factors: carrageenan (10 grams and 20 grams) and the addition of pedada juice extract (control, $50 \mathrm{ml}, 100 \mathrm{ml}$ ) obtained 6 combinations. To find out the acceptability, the organoleptic test using the hedonic method using 30 panelists were rather trained. This research was conducted in May-August 2018. Jelly candy making and organoleptic test was carried out at the STIKes Baiturrahim Jambi Nutrition and Food Laboratory. The best treatment in making Pedada jelly candy which is very preferred, namely P2K2 (100 ml pedada fruit juice and 20 gr carrageenan) with a color score of 5.87, taste 4.74, flavour 4.74, texture 5.28.
\end{abstract}

Keywords: acceptability, carrageenan, jelly candy, pedada fruit

\begin{abstract}
Abstrak
Buah pedada (Sonneratia caseolaris) merupakan salah satu varietas mangrove yang memiliki kandungan gizi yang tinggi dan berpotensi sebagai antioksidan. Secara umum buah pedada masih kurang dimanfaatkan oleh masyarakat karena rasanya yang asam dan terasa sepat jika dikonsumsi langsung. Salah satu upaya dalam pemanfaatan buah pedada tersebut yaitu mengolahnya menjadi permen jelly. Penelitian ini bertujuan ini untuk mengetahui daya terima (warna, aroma, tekstur dan rasa) permen jelly buah pedada dengan penambahan karagenan. Penelitian ini merupakan desain eksperimen menggunakan rancangan acak lengkap (RAL) 2 faktor yaitu karagenan (10 gram dan 20 gram) dan penambahan sari buah pedada (kontrol, $50 \mathrm{ml}, 100 \mathrm{ml}$ ) diperoleh 6 kombinasi untuk mengetahui daya terima digunakan uji organoleptik metode hedonik dengan menggunakan 30 orang panelis agak terlatih. Penelitian ini telah dilaksanakan pada bulan Mei-Agustus 2018, pembuatan permen jelly dan uji organoleptik dilakukan di Laboratorium Gizi dan Pangan STIKes Baiturrahim Jambi. Daya terima permen jelly buah pedada dengan perlakuan terbaik yang sangat disukai yaitu P2K2 (100 ml sari buah pedada dan 20 gr karagenan) dengan skor warna 5,87, rasa 4,74, aroma 4,74 dan tekstur 5,28.
\end{abstract}

Kata kunci : buah pedada, daya terima, karagenan, permen jelly

\section{PENDAHULUAN}

Salah satu negara yang memiliki hutan mangrove serta memiliki kekayaan hayatinya adalah Indonesia, dengan luas antara 2,5 hingga 4,5 juta hektar merupakan mangrove yang terluas didunia (Kusmana, 2008). Kabupaten Tanjung Jabung Barat yang berada di Pantai Timur Provinsi Jambi dikenal sebagai kawasan hutan mangrove yang menjadi salah satu wilayah untuk 
melestarikan pantai. Hutan mangrove mempunyai banyak varietas yang dapat dimanfaatkan oleh masyarakat sekitar untuk meningkatkan perekonomian salah satunya buah pedada dengan spesies Sonneratia caseolaris (Sari, 2013).

Buah pedada merupakan buah yang bagian dasarnya terbungkus kelopak bunga, berbentuk bola, dan ujung buahnya bertangkai. Buah pedada tidak beracun dan langsung dapat dimakan buah pedada memilki rasa yang asam dan aroma yang khas. Buah pedada banyak ditemui di daerah perairan payau yang merupakan tempat bertumbuhnya tanaman mangrove (Susanto et al., 2008). Buah pedada (Sonneratia caseolaris) dapat dimanfaatkan sebagai sumber pangan (Septiadi, 2010). Daging buah pedada memiliki kandungan gizi yang tinggi. Kandungan gizi per $100 \mathrm{~g}$ buah pedada segar terdapat karbohidrat $77,5 \%$, protein $9,21 \%$, lemak $4,81 \%$, vitamin $A$ $11,21(\mathrm{RE})$, vitamin $\mathrm{B}_{1} 5,04 \mathrm{mg}$, vitamin $\mathrm{B}_{2}$ 7,65 mg dan vitamin C 56,74 mg (Manalu, 2011) serta memiliki kadar air $67,8 \%$ dan kadar abu 1,17\% (Ramadani et al, 2019). Buah pedada merupakan salah satu tumbuhan yang berpotensi sebagai antioksidan, tumbuhan ini mengandung senyawa alkaloid, flavonoid, glikosida, saponin dan fenol (Avenido dan Serrano, 2012).

Secara umum buah pedada masih kurang dimanfaatkan oleh masyarakat karena rasanya yang asam dan terasa sepat jika dikonsumsi langsung. Kandungan kadar airnya yang tinggi hingga $79 \%$ menyebabkan buah pedada mudah membusuk (Febrianti, 2010). Buah pedada memiliki kandungan gizi dan antioksidan yang belum dimanfaatkan dan buah tersebut biasanya hanya dibiarkan berjatuhan begitu saja sehingga berserakan dan tidak termanfaatkan dengan baik oleh masyarakat sekitarnya, sehingga perlu dilakukan pengolahan agar buah pedada dapat dimanfaatkan dengan baik dan dapat dijadikan sebagai sumber pangan. Salah satu upaya dalam pemanfaatan buah pedada tersebut yaitu mengolahnya menjadi permen jelly (Afriyanto et al., 2016).

Permen jelly merupakan permen yang terbuat dari campuran sari buah-buahan, bahan pembentuk gel atau dengan penambahan komponen flavoring untuk menghasilkan berbagai macam rasa dengan bentuk fisik jernih dan transparan (Atmaka et al., 2013).

Bahan utama dalam pembuatan permen jelly menurut SNI No. 3547.2.2008 tahun 2008 adalah gula, penambahan komponen hidrokoloid seperti agar, gum, pektin, pati, karagenan, gelatin dan lain-lain yang digunakan untuk modifikasi tekstur sehingga menghasilkan produk yang kenyal.

Dalam penelitian ini, bahan tambahan yang digunakan adalah karagenan. Karagenan merupakan salah satu gelling agent yang dapat digunakan pada pembuatan permen jelly. Karagenan merupakan getah rumput laut yang diperoleh dari hasil ekstraksi rumput laut merah dengan menggunakan air atau larutan alkali pada suhu yang tinggi (Muchlisah, 2012). Karagenan memiliki kandungan serat, kaya akan komponen seperti karbohidrat, protein, lemak, enzim, asam nukleat, asam amino, mineral, dan vitamin A, B, C, D, E, dan K (Karyani, 2013) dan memiliki kandungan unsur-unsur mineral makro yaitu kalsium sebesar 186,00 ppm dan fosfor sebesar 2,76 ppm serta unsur mineral mikro yaitu besi sebesar 2,12 ppm (Winarno, 2008). Karagenan mempunyai sifat fungsional yang sangat baik dan berguna untuk mengontrol kadar air dan berfungsi sebagai sistem yang menstabilkan dalam pangan, memperbaiki tekstur dan sistem fungsional (Langendorff et al., 2000).

Maka berdasarkan uraian diatas, perlu dilakukan pengolahan untuk meningkatkan pemanfaatan buah pedada (Sonneratia 
caseolaris) dan mendapatkan bahan pangan bergizi yang murah dan mudah didapat serta menjadi inovasi olahan produk yang baru maka peneliti tertarik untuk memanfaatkan buah pedada sebagai bahan baku pembuatan permen jelly, dengan tujuan untuk mengetahui pengaruh penambahan karagenan terhadap karakteristik kimia pada produk permen jelly pedada. Berdasarkan perlakuan terbaik pada penelitian permen jelly buah pedada dengan penambahan karagenan Afriyanto et al (2016) maka dalam penelitian ini, perlakuan yang digunakan yaitu konsentrasi sari buah $0 \mathrm{ml}, 50 \mathrm{ml}$ dan $100 \mathrm{ml}$ serta karagenan sebesar 10\%, $20 \%$ dengan modifikasi berdasarkan penelitian pendahuluan. Sehingga diharapkan hasil penelitian ini dapat menjadi referensi dalam menghasilkan produk permen jelly buah pedada dengan daya terima terbaik.

\section{METODE PENELITIAN}

Penelitian ini merupakan desain eksperimen dengan menggunakan rancangan acak lengkap (RAL), dengan 2 faktorial. Faktor I yaitu sari buah pedada $(50 \mathrm{ml}$ dan $100 \mathrm{ml}$ ) dan faktor II yaitu karagenan (10 gr dan 20 gr) untuk permen jelly buah pedada. Dari kedua faktor perlakuan diperoleh 6 macam kombinasi. Parameter yang dianalisis dalam penelitian ini adalah daya terima konsumen (warna, rasa, aroma, tekstur).

Adapun kombinasi perlakuan antara penambahan sari buah pedada dan karagenan adalah sebagai berikut :

P0K1 = Kontrol (tanpa sari buah pedada) dengan karagenan $10 \mathrm{gr}$

P0K2 = Kontrol (tanpa sari buah pedada) dengan karagenan $20 \mathrm{gr}$

$\mathrm{P} 1 \mathrm{~K} 1=$ Sari buah pedada $50 \mathrm{ml}$ dengan karagenan 10 gr

$\mathrm{P} 1 \mathrm{~K} 2$ = Sari buah pedada $50 \mathrm{ml}$ dengan karagenan 20 gr

$\mathrm{P} 2 \mathrm{~K} 1$ = Sari buah pedada $100 \mathrm{ml}$ dengan karagenan 10 gr
$\mathrm{P} 2 \mathrm{~K} 2$ = Sari buah pedada $100 \mathrm{ml}$ dengan karagenan 20 gr

\section{Pelaksanaan Penelitian Waktu dan Tempat Penelitian}

Penelitan dilaksanakan pada bulan MeiAgustus 2019. Tempat pembuatan dan uji organoleptik permen jelly akan dilaksanakan di Laboratorium Gizi dan Pangan Stikes Baiturrahim Jambi.

\section{Bahan dan Alat Penelitian}

Alat yang digunakan untuk pembuatan permen jelly buah pedada yaitu panci, spatula, baskom, blender, timbangan, kain saring, loyang, gelas ukur, oven.

Bahan yang digunakan untuk pembuatan permen jelly yaitu buah pedada (Sonneratia caseolaris) yang diperoleh dari Kabupaten Tanjung Jabung Barat Kecamatan Manunggul, sukrosa, sirup fruktosa $55 \%$, asam sitrat, karagenan, air.

\section{Prosedur Pembuatan}

\section{Pembuatan Sari Buah Pedada}

Proses pembuatan sari buah pedada mengacu pada Afriyanto et al (2016). Pembuatan diawali dengan penghancuran buah pedada. Pedada dipilih dengan kriteria masih segar dan tidak busuk. Buah pedada dibersihkan dengan air yang mengalir, kemudian dikupas lalu buah pedada dipotong-potong dan dihancurkan dengan menggunakan blender sambil ditambahkan air sebanyak 1:1. Hancuran buah pedada kemudian disaring menggunakan kain agar biji tidak tercampur untuk diambil sari buah pedada.

\section{Pembuatan Permen Jelly}

Proses pembuatan permen jelly mengacu pada Nursyamsiati (2013) dan Isnanda et al (2016). Sirup fruktosa dan sukrosa dipanaskan sampai larut. Kemudian masukan karagenan sesuai rasio perlakuan 
dilarutkan dengan sari buah pedada. Kemudian dipanaskan hingga mencapai suhu $80-100^{\circ} \mathrm{C}$ (selama 10 menit) sambil diaduk sampai mengental, kemudian suhu diturunkan dan ditambahkan asam sitrat sambil diaduk lalu dituangkan ke dalam loyang atau cetakan. Adonan didalam loyang didiamkan selama 10 jam dalam suhu ruang lalu dipotong. Kemudian dikeringkan dalam oven selama 3 jam pada suhu $50-70^{\circ} \mathrm{C}$ selama 3 jam.

\section{Prosedur Pelaksanaan Uji Organoleptik}

Uji organoleptik yang digunakan menggunakan metode uji penerimaan yang juga disebut acceptance tests atau preference tests. Uji penerimaan yang digunakan adalah uji hedonik yang menyatakan suka atau tidak suka terhadap suatu produk. Pelaksanan pengujian dilakukan oleh 30 panelis agak terlatih yang terdiri dari mahasiswa S1 Ilmu Gizi Sekolah Tinggi Ilmu kesehatan Baiturrahim Jambi yang sudah lulus mata kuliah teknologi pangan.

Cara pengujian dengan menyiapkan sampel secara acak setelah diberi kode sesuai rancangan percobaan. Sampel permen jelly buahpedada seberat 2 gr pada tiap-tiap perlakuan diletakan didalam wadah kemudian disajikan dihadapan panelis.

Panelis diberi arah tentang tata cara penilaian, kemudian panelis diminta untuk mencicipi sampel dari perlakuan selanjutnya. Panelis memberikan penilaian dan mengisi lembar pernyataan yang tersedia. Penilaian dimulai dari skor 1 sangat tidak suka sampai amat sangat suka dengan skor 7 .

\section{HASIL DAN PEMBAHASAN}

Daya terima keseluruhan terhadap makanan dapat diukur dari segi warna, aroma, rasa dan tekstur (Irmawati et al., 2014). Berikut hasil analisis daya terima permen jelly buah pedada (Tabel 1).

Tabel 1 Hasil Analisis Daya Terima Permen Jelly Buah Pedada

\begin{tabular}{cccccc}
\hline Perlakuan & Warna & Rasa & Aroma & Tekstur & Overall \\
\hline P0K1 & $4,59^{\mathrm{ab}}$ & $2,40^{\mathrm{a}}$ & $3,67^{\mathrm{a}}$ & $2,61^{\mathrm{a}}$ & $3,31^{\mathrm{a}}$ \\
P0K2 & $4,18^{\mathrm{a}}$ & $2,75^{\mathrm{a}}$ & $3,70^{\mathrm{a}}$ & $2,83^{\mathrm{a}}$ & $3,35^{\mathrm{a}}$ \\
P1K1 & $5,02^{\mathrm{c}}$ & $4,09^{\mathrm{b}}$ & $3,86^{\mathrm{a}}$ & $4,37^{\mathrm{b}}$ & $4,37^{\mathrm{b}}$ \\
P1K2 & $5,14^{\mathrm{bc}}$ & $4,08^{\mathrm{b}}$ & $3,89^{\mathrm{a}}$ & $5,19^{\mathrm{c}}$ & $4,55^{\mathrm{bc}}$ \\
P2K1 & $5,42^{\mathrm{cd}}$ & $4,29^{\mathrm{b}}$ & $4,34^{\mathrm{ab}}$ & $5,09^{\mathrm{c}}$ & $4,79^{\mathrm{cd}}$ \\
P2K2 & $5,87^{\mathrm{d}}$ & $4,74^{\mathrm{b}}$ & $4,74^{\mathrm{b}}$ & $5,28^{\mathrm{c}}$ & $5,16^{\mathrm{d}}$ \\
\hline
\end{tabular}

Keterangan :P0K1= Sari buah pedada:karagenan $(0 \mathrm{ml}: 10 \mathrm{gr})$; P0K2= Sari buah pedada:karagenan $(0 \mathrm{ml}: 20$ gr $) ; \mathrm{P} 1 \mathrm{~K} 1=\mathrm{Sari}$ buah pedada:karagenan (50 ml:10 gr); P1K2= Sari buah pedada:karagenan (50 ml:20 gr); P2K1= Sari buah pedada:karagenan (100 ml:10 gr); P2K2= Sari buah pedada:karagenan (100 ml: 20 gr).

(Nilai yang diikuti huruf yang sama setiap kolom menunjukkan nilai tidak berbeda nyata (uji Tukey, $\alpha=0,05$ ). Skor nilai: $1=$ sangat tidak suka, $2=$ tidak suka, $3=$ agak tidak suka,4= agak suka, $5=$ suka, $6=$ sangat suka, $7=$ amat sangat suka

\section{Warna}

Warna merupakan suatu bahan yang berasal dari penyebaran spektrum sinar, begitu juga kilap dari bahan yang dipengaruhi oleh sinar pantul. Warna bukan merupakan suatu zat atau benda melainkan sensasi sensori seseorang karena adanya rangsangan dari seberkas energi radiasi yang jatuh keindra penglihatan (Kartika, 2011). Warna berperan dalam penentuan tingkat penerimaan konsumen terhadap suatu produk, meskipun produk tersebut bernilai gizi tinggi, rasa enak, dan tekstur baik namun jika warna tidak menarik maka akan menyebabkan produk tersebut kurang diminati (Juwita, 2012). 
Hasil uji dengan Two Way Anova menunjukkan bahwa warna permen jelly buah pedada terdapat perbedaan yang signifikan diantara masing-masing perlakuan, ditandai dengan nilai signifikan $\beta<\alpha(0,05)$ yaitu sari buah pedada 0,000 (Lampiran 3). Hasil uji lanjut tukey menunjukkan bahwa penambahan sari buah pedada dan karagenan yang berbeda pada permen jelly buah pedada mempengaruhi warna permen jelly buah pedada.

Dari Tabel 1 dapat diketahui bahwa warna permen jelly buah pedada perlakuan P0K1 dan P0K2 tidak ada perbedaan yang nyata pada taraf $5 \%$, perlakuan $\mathrm{P} 1 \mathrm{~K} 2$ dan P2K1 tidak ada perbedaan nyata pada taraf 5\%. Namun permen jelly buah pedada perlakuan P1K1, P2K2 menunjukan ada perbedaan yang nyata pada taraf $5 \%$.

Permen jelly buah pedada P0K2, P1K1, $\mathrm{P} 1 \mathrm{~K} 2$, P1K2, P2K1 menghasilkan warna yang disukai panelis dan warna perlakuan P2K1 warna yang sangat disukai panelis. Sedangkan perlakuan P0K1 menghasilkan warna yang agak disukai panelis.

Berdasarkan hasil tersebut menunjukkan bahwa tingkat kesukaan parameter warna sampel P2K2 nyata lebih tinggi dibandingkan sampel lain ditandai dengan skor 5,87 dalam kategori sangat suka $(p<0,05)$ (Tabel 1). Berdasarkan komentar yang diberikan panelis sebagian besar panelis menyatakan bahwa warna permen jelly $\mathrm{P} 2 \mathrm{~K} 2$ dengan formulasi $100 \mathrm{ml}$ sari buah pedada dan 20 gr karagenan memiliki warna yang berbeda dengan kontrol, formula yang dihasilkan memiliki warna yang menarik dan lebih jernih dan sesuai kriteria permen jelly. Pada perlakuan ini warna permen jelly lebih banyak ditentukan oleh warna alami sari buah dan hasil pencoklatan selama proses pembuatan permen jelly. Penggunaan sari buah pada perlakuan P2K2 menyebabkan kadar pigmen flavonoid dan hasil reaksi pencoklatan yang semakin rendah pula.
Selain itu pada gel yang kokoh, intensitas warna akan semakin berkurang sehingga penambahan karagenan dapat mengurangi warna coklat pada proses pengolahan permen jelly buah pedada. Reaksi yang terjadi merupakan reaksi pencoklatan non-enzimatis yaitu reaksi karamelisasi yang menyebabkan permen menjadi gelap. Proses tersebut adalah memecah setiap molekul sukrosa menjadi molekul glukosa dan fruktosa, suhu tinggi mampu mengeluarkan molekul air dari setiap molekul gula, sehingga terbentuk glukosan dan fruktosan (dehidrasi). Setelah proses pemecahan dan dehidrasi adalah reaksi polimerisasi yaitu terbentuknya komponen polimer yang berwarna, menyebabkan larutan berwarna gelap (Winarno, 2008).

\section{Rasa}

Rasa didefenisikan sebagai sensasi yang terbentuk dari hasil perpaduan bahan pembentuk dan komposisi pada suatu produk makanan yang ditangkap indera pengecap (Apriliyanti, 2010). Atribut rasa meliputi asin, manis, asam, pahit, dan umami. Sebagian dari atribut ini dapat terdeteksi pada kadar yang sangat rendah. Rasa makanan sangat ditentukan oleh formulasi produk tersebut (Gustiar, 2009). Rasa menjadi faktor yang paling penting dalam menilai produk makanan diterima atau ditolak, karena walaupun aroma, tekstur dan warna baik tetapi rasanya tidak enak, maka konsumen tidak menerima makanan tersebut (Nasrulloh, 2015).

Hasil uji dengan Two Way Anova menunjukkan bahwa rasa permen jelly buah pedada terdapat perbedaan yang signifikan diantara masing-masing perlakuan, ditandai dengan nilai signifikan $\beta<\alpha(0,05)$ yaitu sari buah pedada 0,000. Hasil uji lanjut tukey menunjukkan bahwa penambahan sari buah pedada dan karagenan yang berbeda pada permen jelly buah pedada mempengaruhi rasa permen jelly buah pedada. 
Dari Tabel 1 diatas dapat diketahui bahwa rasa permen jelly buah pedada perlakuan P0K1 dan P0K2 tidak ada perbedaan nyata pada taraf 5\%. Perlakuan $\mathrm{P} 1 \mathrm{~K} 1, \quad \mathrm{P} 1 \mathrm{~K} 2, \quad \mathrm{P} 2 \mathrm{~K} 1, \quad \mathrm{P} 2 \mathrm{~K} 2$ tidak ada perbedaan yang nyata pada taraf $5 \%$.

Permen jelly buah pedada P1K1, P1K2, P2K1 menghasilkan rasa yang agak disukai panelis dan rasa perlakuan $\mathrm{P} 2 \mathrm{~K} 2$ rasa yang disukai panelis. Sedangkan perlakuan P0K2 menghasilkan rasa yang agak tidak disukai panelis dan perlakuan P0K1 menghasilkan rasa yang tidak disukai panelis. Hal ini dikarenakan semakin sedikit penambahan sari buah papaya akan membuat rasa permen jelly yang manis dan sedikit asam berkurang.

Berdasarkan hasil tersebut menunjukkan bahwa tingkat kesukaan parameter rasa sampel P2K2 nyata lebih tinggi dibandingkan sampel lain ditandai dengan skor 4,74 dalam kategori suka $(p<0,05) \quad$ (Tabel 1). Pada perlakuan ini Rasa permen jelly manis sedikit asam, rasa manis berasal dari penambahan sukrosa dan sirup fruktosa. Rasa manis diperoleh dari sukrosa dan fruktosa cair yang digunakan sebagai bahan pemberi rasa dalam permen jelly. Sedangkan rasa asam dari sari buah pedada dan penambahan asam sitrat pada adonan permen jelly. Kadar sukrosa dan fruktosa yang tinggi dapat mengurangi tingkat keasaman permen jelly. Semakin banyak penambahan karagenan cenderung memberikan manis lebih kuat dan semakin sedikit penambahan sari buah pedada cenderung membuat rasa permen jelly yang manis dan sedikit asam berkurang (Yuniarti, 2011).

\section{Aroma}

Aroma makanan berasal dari molekulmolekul yang menguap dari makanan tersebut yang tertangkap hidung sebagai indera pembau , perubahan aroma disebabkan karena adanya degradasi makromolekul karbohidrat seeprti gula menjadi makromolekul yang lebih sederhana menjadi alkohol dan asam-asam organik oleh aktivitas mikroorganisme (Winarno, 2015). Dalam industri pangan aroma atau bau dianggap penting karena cepat dapat memberikan hasil penilaian terhadap produk terkait diterima atau tidaknya suatu produk (Apriliyanti, 2010).

Hasil uji dengan Two Way Anova menunjukkan bahwa aroma permen jelly buah pedada terdapat perbedaan yang signifikan diantara masing-masing perlakuan, ditandai dengan nilai signifikan $f<\alpha(0,05)$ yaitu sari buah pedada 0,000 . Hasil uji lanjut tukey menunjukkan bahwa penambahan sari buah pedada dan karagenan yang berbeda pada permen jelly buah pedada mempengaruhi aroma permen jelly buah pedada.

Dari tabel diatas dapat diketahui bahwa aroma permen jelly buah pedada perlakuan P0K1, P0K2, P1K1, P2K2, P2K1 tidak ada perbedaan yang nyata pada taraf $5 \%$. Namun permen jelly buah pedada perlakuan P2K2 menunjukan ada perbedaan yang nyata pada taraf 5\%.

Permen jelly buah pedada P0K1, P0K2, $\mathrm{P} 1 \mathrm{~K} 1, \mathrm{P} 1 \mathrm{~K} 2$, P2K1 menghasilkan aroma yang agak disukai panelis dan perlakuan P2K2 aroma yang disukai panelis. Hal ini dikarenakan semakin banyak penambahan sari buah padada akan membuat aroma permen jelly yang segar dan bearoma khas buah pedada akan semakin kuat dan menjadi yang disukai panelis.

Berdasarkan hasil tersebut menunjukkan bahwa tingkat kesukaan parameter aroma sampel $\mathrm{P} 2 \mathrm{~K} 2$ nyata lebih tinggi dibandingkan sampel lain ditandai dengan skor 4,74 dalam kategori suka $(p<0,05) \quad$ (Tabel 1). Hal ini dikarenakan semakin banyak penambahan sari buah padada akan membuat aroma permen jelly yang segar dan beraoma khas buah pedada 
akan semakin kuat dan menjadi yang disukai panelis. Berdasarkan hasil uji organoleptik dapat diketahui bahwa aroma yang disukai panelis adalah perlakuan P2K2(100 ml sari buah pedada dan 20 gr karagenan) dengan skor nilai rata-rata 4,74 pada kategori suka. Pada perlakuan ini aroma khas buah pedada pada permen jelly cenderung semakin kuat dikarenakan semakin banyak penambahan sari buah pedada. Buah pedada memiliki aroma asam yang khas pada peneilitian Jariyah et al (2015), buah pedada mengandung asam anhidrogalakturonat sebesar 26,34 \%. Aroma dari hasil pemanasan gula dapat mengimbangi aroma khas pada buah sehingga menghasilkan perpaduan aroma khas. Hal ini sesuai dengan pendapat Afriyanto et al (2016) bahwa sukrosa dapat memperbaiki aroma dan cita rasa dengan cara membentuk keseimbangan yang lebih baik antara keasaman, rasa pahit dan rasa asin, ketika digunakan pada pengkonsentrasian larutan. Bahan penunjang pembentuk permen jelly adalah karagenan. Karagenan yang digunakan merupakan sejenis hidrokoloid yang tidak memiliki komponen volatil sehingga tidak memberikan pengaruh nyata terhadap aroma permen jelly (Bachtiar et al. 2017).

\section{Tekstur}

Tekstur bahan pangan merupakan kumpulan dari sejumlah karakter yang berbeda, yang dirasakan oleh bermacammacam anggota tubuh manusia. Menurut Apriliyanti (2010) tekstur merupakan sensasi tekanan yang dapat diamati dengan menggunakan mulut pada waktu digigit, dikunyah dan ditelan), ataupun dengan perabaan dengan jari.

Hasil uji dengan Two Way Anova menunjukkan bahwa tekstur permen jelly buah pedada terdapat perbedaan yang signifikan diantara masing-masing perlakuan, ditandai dengan nilai signifikan $\beta<\alpha(0,05)$ yaitu sari buah pedada 0,000 . Hasil uji lanjut tukey menunjukkan bahwa penambahan sari buah pedada dan karagenan yang berbeda pada permen jelly buah pedada mempengaruhi tekstur permen jelly buah pedada.

Dari tabel diatas dapat diketahui bahwa tekstur permen jelly buah pedada perlakuan P0K1, P0K2 tidak ada perbedaan yang nyata pada taraf 5\%. Perlakuan P1K2, P2K1 tidak ada perbedaan yang nyata pada taraf $5 \%$. Namun permen jelly buah pedada perlakuan P1K1 dan P2K2 menunjukan ada perbedaan yang nyata pada taraf $5 \%$.

Permen jelly buah pedada P1K2, P2K1, P2K2 menghasilkan tekstur yang disukai panelis dan perlakuan P1K1 menghasilkan tekstur,yang agak disukai panelis. Sedangkan perlakuan P0K1 dan P0K2 menghasilkan tekstur yang agak tidak disukai panelis.

Berdasarkan hasil tersebut menunjukkan bahwa tingkat kesukaan parameter tekstur sampel P2K2 nyata lebih tinggi dibandingkan sampel lain ditandai dengan skor 5,28 dalam kategori suka $(p<0,05) \quad$ (Tabel 4.1). Hal ini disebabkan adanya perbedaan persentase sari buah pedada dan karagenan. Dari hasil uji organoleptik dapat diketahui bahwa tekstur terbaik adalah perlakuan P2K2 (100 ml sari buah pedada dan 20 gr karagenan) dengan skor nilai rata-rata 5,28 dalam kategori suka. Berdasarkan komentar yang diberikan oleh panelis sebagian besar panelis menyatakan bahwa tekstur permen jelly dengan formulasi $100 \mathrm{ml}$ sari buah pedada dan 20 gr karagenan lebih disukai dan mempunyai tekstur yang kenyal. Hal ini disebabkan oleh penambahan persentase karagenan. Bahan pembentukan gel pada penelitian ini adalah karagenan. Karagenan merupakan hidrokoloid yang berfungsi membentuk tekstur seperti gel dalam pembuatan permen jelly buah pedada. Pembentukan gel adalah penggabungan atau pengikatan silang rantai-rantai polimer 
sehingga terbentuk suatu jaringan tiga dimensi. Jaringan ini mengikat air di dalamnya dan membentuk tekstur yang kuat (Bachtiar et al. 2017). Semakin banyak penambahan karagenan cendrung memberikan tekstur semakin kenyal. Menurut Jumri (2014), semakin banyak penambahan karagenan cenderung memberikan tekstur yang kuat. Hal ini sesuai dengan pendapat Salamah et al. (2006) dan Harijono et al. (2001) pada kadar karagenan yang tinggi menghasilkan tekstur permen jelly yang kuat.

\section{Overall}

Penilaian overall pada uji organoleptik yang dilakukan oleh panelis meliputi penilaian secara keseluruhan terhadap warna, rasa, aroma dan tekstur permen jelly buah pedada. Hasil penilaian overall oleh panelis pada uji organoleptik terhadap warna, rasa, aroma dan tekstur permen jelly buah pedada dapat dilihat pada Tabel 4.1.

Hasil uji dengan Two Way Anova menunjukkan bahwa overall permen jelly buah pedada terdapat perbedaan yang signifikan diantara masing-masing perlakuan, ditandai dengan nilai signifikan $f<\alpha(0,05)$ yaitu sari buah pedada 0,000 (Lampiran 7). Hasil uji lanjut tukey menunjukkan bahwa penambahan sari buah pedada dan karagenan yang berbeda pada permen jelly buah pedada mempengaruhi overall permen jelly buah pedada (Lampiran 7).

Dari tabel diatas dapat diketahui bahwa overall permen jelly buah pedada perlakuan P0K1, P0K2 tidak ada perbedaan yang nyata pada taraf 5\%. Perlakuan P1K1 dan P1K2 tidak ada perbedaan yang nyata pada taraf 5\%. Namun permen jelly buah pedada perlakuan P2K1 dan P2K2 menunjukan ada perbedaan yang nyata pada taraf $5 \%$. Permen jelly buah pedada P2K2 menghasilkan overall yang disukai panelis dan perlakuan P1K1, P1K2, P2K1 menghasilkan overall,yang agak disukai panelis. Sedangkan perlakuan P0K1 dan P0K2 menghasilkan tekstur yang agak tidak disukai panelis.

Berdasarkan hasil analisis organoleptik didapatkan overall terbaik yaitu perlakuan P2K2 (100 ml sari buah pedada dengan 20 gram karagenan) dengan skor nilai 5,16 dalam kategori suka dan merupakan perlakuan terbaik bagi panelis. Berdasarkan komentar yang diberikan oleh panelis permen jelly dengan perlakuan P2K2 (100 ml sari buah pedada dan 20 gr karagenan), cenderung lebih disukai karena teksturnya yang kenyal, rasa yang lebih asam-manis, warna yang jernih dan aroma yang khas buah pedada. Hal ini sesuai dengan pendapat Irmawati et al., (2014) yang menyatakan bahwa penilaian daya terima keseluruhan terhadap makanan dapat diukur dari segi warna, aroma, rasa dan tekstur.

\section{SIMPULAN}

Daya terima permen jelly buah pedada (Sonneratia caseolaris) dengan penambahan karagenan dengan perlakuan yang paling disukai adalah perlakuan P2K2 (100 ml sari buah pedada dan 20 gr karagenan) dengan skor warna 5,87 (Sangat suka), rasa 4,74 (suka), aroma 4,74 (suka) tekstur 5,28 (suka) dan overall 5,16 (suka).

Untuk penelitian selanjutnya konsentrasi sari buah pedada perlu diturunkan dan karagenan terbaik digunakan 20 gram pada pembuatan permen jelly serta perlu dilakukan penelitian lebih lanjut permen jelly buah pedada dengan penambahan karagenan untuk memenuhi syarat mutu SNI 3547-2-2008 pada kadar air dan kadar abu permen jelly dan perlu dilakukan uji mikroba dan penyimpanan pada permen jelly buah pedada.

\section{DAFTAR PUSTAKA}

[BSN] Badan Standardisasi Nasional. 2008. SNI 3547.2.2008 Kembang Gula- 
Bagian 2: Lunak. Badan Standardisasi Nasional: Jakarta.

[BSN] Badan Standardisasi Nasional. 1992. SNI 01-2891-1992. Cara Uji Makanan dan Minuman. Badan Standardisasi Nasional: Jakarta.

Afriyanto, Akhyar, A., Rahmayuni. 2016. Pengaruh Penambahan Karagenan Terhadap Mutu Permen Jelly Dari Buah Pedada. Jurnal Jom Faperta 3(2): 1-9.

Apriliyanti, T. 2010. Kajian Sifat Fisikokimia dan sensori tepung ubu jalar ungu (Ipomoea batatas blackie) dengan Variasi proses pengeringan. Skripsi. Universitas Sebelas Maret. Surakarta

Atmaka, W., Nurhartadi, E., Karim, M. 2013. Pengaruh Penggunaan Campuran Karagenan dan Konjak Terhadap Karakterisik Permen Jelly Temulawak (Curcuma xanthorrhiza Roxb.). Jurnal Teknosains Pangan, 2 (2). ISSN: 23020733.

Avenido, P dan Serrano, A.E. 2012. Effects Of The Apple Mangrove (Sonneratia Caseolaris) On Growth, Nutrient Utilization And Digestive Enzyme Activities Of Theblack Tiger Shrimp Penaeus Monodon Postlarvae. European Journal of Experimental Biology.

Bactiar, N., Ali, A., Rossi, A E. 2013. Pembuatan Permen Jelly Ekstra Jahe Merah Dengan Penambahan Karagenan. Jurnal Jom Faperta 4(1):113.

Febrianti, F. 2010. Kandungan Total Fenol, Komponen Bioaktif, Dan Aktivitas Antioksidan Buah Pedada (Sonerattia caseolaris). Skripsi Fakultas Perikanan dan Ilmu Kelautan Institut Pertanian: Bogor.

Gustiar, H. 2009. Sifat fisko-kimia dan indeks glikemik produk cookies berbahan baku pati garut (maranta arundinacea L.)
Termodifikasi. Skripsi. Fakultas teknologi pertnian .IPB.Bogor.

Harijono., Kusnadi,J. dan S. A. Mustikasari. 2001. Pengaruh Kadar karagenan dan total padatan terlarut sari buah apel muda terhadap aspek kualitas permen Jelly . Jurnal Teknologi Pertanian, 2(2): $110-116$.

Irmawati, F.M., D. ishartani, dan D.R. Affandi. 2014. Pemanfaatan tepung umbi garut (Maranta arundinacea L) sebagai pengganti terigu dalam pembuatan biscuit tinggi enrgi protein dengan penambhaan tepung kacang merah (Phaseolus vulgaris L). Jurnal Teknosains Pangan 3(1) ISSN: 23020733.

Isnanda, D., Novita, M., Rohayah, S. 2016. Pengaruh Konsentrasi pectin dan Karagenan Terhadap Permen Jelly Nanas (Ananas comosus L. Merr). Jurnal Ilmiah Mahasiswa Pertanian Unsyiah 1(10): 912-923.

Jariyah. 2013. Efek hipoglemik tepung pedada (Sonneratia caseolaris) pada tikus wistar yang diinduksi aloksan. Disertasi Doktor Universitas Pembangunan Nasional "Veteran" Jawa Timur : Surabaya.

Jumri. 2014. Mutu permen jelly buah naga merah (Hylocereus polyrhizus) dengan penambahan karagenan dan gum arab. Skripsi. Fakultas Pertanian, Universitas Riau. Pekanbaru.

Juwita, Z. 2010. Formulasi dan nilai indeks glikemik cookies ganyong (Cannasedulis Kerr). Skripsi Institut pertanian bogor.

Kartika, B. 1988. Pedoman uji inderawi bahan pangan. Pusat antar universitas pangan dan gizi. Universitas pangan dan gizi. Universitas gajah mada. Yogyakarta.

Karyani, Said. 2013. Analisis Kandungan Food Grade Pada Karagenan Dari 
Ekstraksi Rumput Laut Hasil Budidaya Nelayan Seram Bagian Barat. Jurnal Bimafika 4(1):499-506.

Kusmana, C., Dodi, S., Nyoto, S., Rinekso, S. 2008. Ekologi Tumbuhan Pedada (Sonneratia caseolaris (L) Engler 1987) pada kawasan Muara Angke Propinsi Daerah Khusus Ibukota Jakarta. Jurnal KKMN 54(8):1-4.

Langendorff, V., Cuvelier, G., michon, C., Launay, B., Parkek, A., De kruif, C.G. 2000. Effects of carrageenan type on the behavior of carrageenan or milk mixtures. FOOD Hydrocolloids. 14(1): 273-280.

Manalu. 2011. Kadar Beberapa Vitamin Pada Buah Pedada (Sonneratia caseolaris) Dan Hasil Olahannya. Skripsi Departemen Teknologi Hasil Perairan. Fakultas Perairan dan Ilmu Kelautan Institut Pertanian Bogor:Bogor.

Muchlisah. 2012. Studi Proses Produksi Karaginan Murni (Refine carrageenan) Dari Rumput Laut Eucheuma cottonii Secara Ohmic : Pengaruh Lama Ekstraksi Dan Suhu Alkalisasi. Skripsi. Program Studi Keteknikan Pertanian Jurusan Teknologi Pertanian Fakultas Pertanian Universitas Hasanuddin Makassar: Makasar.

Nursyamsiati. 2013. Studi Pembuatan Permen Jelly Ubi Jalar Ungu (Ipomea batatas L.) dan Rumput Laut (Eucheuma cottonii). Skripsi. Program Studi Teknologi Hasil Pertanian Fakultas Pertanian Universitas Riau: Pekanbaru.

Ramadani, D.W., Meilina, M., Arsita, Y., Dari, D.W., Safitri, N. 2019. Pengaruh penambahan gula terhadap karakteristik kimia sirup pedada (Sonneratia Caseolaris). Prosiding S1 Ilmu Gizi STIKes Baiturrahim: Jambi.
Salamah, E., A. C. Erungan dan Y. Retnowati. 2006. Pemanfaatan gracilaria $s p$ dalam Pembuatan Permen Jelly. Buletin Teknologi Hasil Perikanan. Vol. $9: 38-46$.

Sari, Y. 2013. Al Akhmar, Ciptakan Sirup dari Buah Pedada .http://www. Jambiup date.co. (Diakses pada tanggal 2 Januari 2019).

Septiadi, A. 2010. Mangrovepun Menghasilkan Pangan Bergizi. http://www.

Kesehatan.kompasiana.com. (Diakses pada tanggal 2 Januari 2019).

Susanto, N., Kusmana, C., Sudarma, D., Sukmadi, R. 2008. Ekologi Tumbuhan Pedada (Sonneratia caseolaris) (L) Engler 1987 Pada Kawasan Muara Angke Provinsi Daerah Khusus Ibu Kota Jakarta. Jurnal KKMN.

Winarno, F. G. 2008. Kimia Pangan dan Gizi. Gramedia Pustaka. Jakarta.

Yuniarti, A. 2011. Kadar zat besi, serat, gula total, dan daya terima permen Jelly dengan penambahan rumput laut Gracilaria $S p$ dan Sargassum Sp.Skripsi. Program Studi Ilmu Gizi Fakultas Kedokteran Universitas Diponegoro. Semarang. 